\title{
Nietzsche, Post-Modernism and Humanitarianism
}

\author{
Jan-Erik Lane \\ Public Policy Institute, Belgrade, Serbia \\ Email: janeklane@gmail.com
}

How to cite this paper: Lane, J.-E. (2018). Nietzsche, Post-Modernism and Humanitarianism. Sociology Mind, 8, 95-106. https://doi.org/10.4236/sm.2018.82007

Received: December 1, 2017 Accepted: March 19, 2018

Published: March 22, 2018

Copyright $\odot 2018$ by author and Scientific Research Publishing Inc. This work is licensed under the Creative Commons Attribution International License (CC BY 4.0).

http://creativecommons.org/licenses/by/4.0/

\begin{abstract}
The emergence of post-modernism in social theory changed Nietzsche's evaluation. Will now its demise lead to a new appreciation of the master in Engadin, Switzerland? His major theory of social stratification is completely out of date. Humanitarianism will replace its inhuman brutality, backed by flawed concepts from Oriental mysticism that Danish genius Kierkegaard made obsolete in his new choice theory.
\end{abstract}

\section{Keywords}

Nietzsche, Kierkegaard, Social Stratification, Individual Choice

\section{Introduction}

The entry on Friedrich Nietzsche (1844-1900) in the Stanford Encyclopaedia of Philosophy (Lanier Anderson, 2017) indicates that post-modernism has been conducive to a fundamental re-evaluation of his philosophy. As the literature on Nietzsche increases, his anticipation of subjectivism, perspectivism and secularism is more and more the centre of the comments and research in humanities and social sciences. But his political philosophy falters badly, being completely out of date with humanitarianism, or the moral theory of humanity.

The secret behind Nietzsche's original style of writing was that he possessed a set of tenets that he repeated almost endlessly in book after booklet, with small variation and perhaps also covering a few contradictions. One of these theses is the complete acceptance of social stratification, especially in its moral implications. This is hardly the Nietzsche that post-modernists praise-epistemologically and ontologically-for his individualism, subjectivism and perspectivism. Post-modernism is in its political entailment fundamentally egalitarian, but Nietzsche rejects this stance most forcefully. In this paper I will analyse his aristocratism-the rule of the "noble", which goes against post-modernism. 


\section{Nietzsche and Post-Modernism}

The reputation of Nietzsche during the twentieth century shifted from weekly negative to strongly positive with the subsequent rise of post-modernism. When he finished publishing, the so-called revolution in philosophy was under way, i.e. the rise of analytical philosophy along the Frege-Russell approach, underlying logic and semantics. Nietzsche did not at all fit into this movement or set of movements (Cambridge, Oxford, Vienna and Uppsala as well as Harvard) that came to dominate philosophy in the first half of the $20^{\text {th }}$ century. It is his individualism, existentialism, perspectivism, nihilism and expressionism that have caught the attention of great post-modernists, like e.g. Heidegger, Foucault, Deleuze and Sartre as well as Rorty and Feyerabend.

Instead, the legacy of Nietzsche faced an upward struggle to disassociate itself from the emerging fascism. Nietzsche was said to be a forerunner of racism and anti-intellectualism in the inter-war Europe, a doctrine exploited by the German Nazis with help from his sister who had manipulated his late publications when he was mad. Analysing Nietzsche's stance towards aristocracy and social stratification makes one realises that he would not have supported the German thugs, as his ideal was none other than Goethe and his contempt for "herds" limitless.

The emergence of post-modernism after the Second World War changed all of this, as post-modernists sought inspiration in inter alia Nietzsche for their credos:

- Language: the post-modern world is "Saussurian": when language is seen as holistically a closed set of opposites, forming a complex web of inter-connected meanings, not disclosable by the methods of analytical philosophy; language is not only a set of Apollonian signs with Nietzsche but harbours a deeper Dionysian well of emotions and hidden assumptions as well as volitions;

- Complex reality: what is "real" may not be easily captured by abstract words or concepts, as a theory is a kind of discourse, comprising "stories" that are inter-connected in huge word webs that must be de-constructed into simpler forms, or more concrete visions;

- Contradictory narratives: the webs of hypotheses constituting our knowledge are not coherent, as different storytelling is always possible; one must allow for multiple presentations of facts, or so-called "meta-narratives";

- Ambiguity of words: the set of words or terms is systematically ambiguous and opaque, so that any notion of truthful representation of the "outside" world is out of the question; facts and interpretations are inter-connected; all words are theory loaded and sometime value-loaded too;

- Diversity: absolute truth is a misnomer, as alternative storytelling is always feasible and the variety of interpretations sustains an intellectual chaos that can only be de-constructed into its basic components, or stories or projects; rigour may actually be an obstacle to scientific progress or intellectual insights; 
- Power: real life and its power structures permeate all storytelling and words are not neutral in its social consequences; instead economic power is vested in the projects scholars engage in, which calls for an examination of the inter-connections between the representation of the world and theory construction; story telling serves social or practical purposes.

Nietzsche anticipated some of these theses in his voluntarist approach to philosophy, epistemology, ontology and morality.

With the now declining trend for postmodernists' philosophy, one may ask whether Nietzsche's star will also fade. The new global trend underlines the basic interests of mankind-humanity, peace, equality, feminism, rights, compassion-that Nietzsche rejected in favour of the values of aristocracy. Will he perhaps go out of data?

\section{Nietzsche's Texts}

Due to his illness, Nietzsche could only benefit from a short period of creativity, from his first book in 1872 (Nietzsche, 1999) to his final collapse in 1889. However, he was extremely productive with almost 10 books or booklets, including the large studies (Nietzsche, 1996b; 1997b; 2001). The last publications, edited by his sister, cannot be taken into consideration. His style of writing became more and more based upon the aphorism model, sometime very short and sometimes quite long. His manner of writing became more uncompromising, if not drastic, the more damage and suffering his illness caused him (Young, 2010; Tanner, 2011; Magnus \& Higgins, 1996).

There is logic in the succession of books or booklets, namely a set of key themes with connected theses propagated by Nietzsche. To capture the themes and the corresponding tenets, one must take into consideration the whole set of books and booklets, following how he treats the themes and formulates his tenets. One should not include books where authenticity is problematic, published after his madness, or works that are more poetic in nature than discursive, like Also Sprach Zarathustra (1883). We know in reality nothings about this Persian man under this name, when he lived for instance or what he preached. He is said to propagate monotheism and eschatology in connection dualism, focusing upon the magic of fire. But we have little evidence. It is all a display of Nietzsche's mastery of German language.

Here, we document first his endorsement of social stratification.

\section{Social Stratification and Its Morality}

All known human societies have been stratified somehow with higher and lower strata identified in accordance with a set of criteria. Whatever the mechanisms of selection have been, social stratification results in a distribution of wealth and power.

The two basic explanations are:

a) Functionalism (Davis \& Moore, 1945): From the perspective of the market 
economy, social stratification fulfils so-called "functional imperatives", allocating rewards according to merit, enhancing overall social and economic efficiency. Differential achievements must be rewarded to maintain incentives to performance.

b) Marxism: The class society of the bourgeoisie with its big classes and numerous strata according to income, wealth and prestige and power is based upon exploitation and will be abolished in time after the necessary revolution of the proletariat.

To these two alternative approaches, we now add Nietzsche's moral theory of stratification. In Beyond Good and Evil (1886), we read a full stamen of his theory of stratification of societies:

"Every enhancement so far in the type "man" has been the work of an aristocratic society-and that is how it will be, again and again, since this sort of society believes in a long ladder of rank order and value distinctions between men, and in some sense needs slavery." (Nietzsche, 2000: p. 151)

Nietzsche is seen as the father of moral nihilism, but beyond Christian good and evil there is to him a set of absolute values, which he calls "noble". Noble values, or the valuation of the nobility must be uphold in every society, whatever thee costs, because they substantiate the essence of men and women. We quote again:

"Without the pathos of distance as it grows out of the ingrained differences between stations, out of the way the ruling caste maintains an overview and keeps looking down on subservient types and tools, and out of this caste's equally continuous exercise in obeying and commanding, in keeping away and below - without his pathos, that other, more mysterious pathos could not have grown at all, that demand for new expansions of distance within the soul itself, the development of states that are increasingly high, rare, distant, tautly drawn and comprehensive, and in short, the enhancement of the type "man", the constant "self-overcoming of man" (to use a moral formula in a supra-moral sense). (Nietzsche, 2000: p. 151)

The rationale of social stratification is not rewarding self-interests to achieve Pareto-optimality or exploit weaker strata for egoistic interests, but-says Nietzsche in the same section:

"Its fundamental belief must always be that society cannot exist for the sake of society, but only as the substructure and framework for raising an exceptional type of being up to its higher duty and to a higher state of being." (Nietzsche, 2000: p. 152)

Nietzsche endorses all forms of social stratification throughout history, even slavery and serfdom, because such rules institutionalise his moral values beyond good and evil. The lower strata have to support the higher strata due to a basic moral rationale, i.e. society is for the benefits of the noble type of person because they and only they create value:

"The noble type of person feels that he determines value, he does not need 
anyone's approval, he judges that "what is harmful to me is harmful in itself," he knows that he is the one who gives honour to things in the first place, he creates values. He honours everything he sees in himself: this sort of morality is self-glorifying. In the foreground, there is the feeling of fullness, of power that wants to overflow, the happiness associated with a high state of tension, the consciousness of a wealth that wants to make gifts and give away." (Nietzsche, 2000: p. 154)

This section on the "aristocratic society" is the longest elaboration of his theory of social stratification as based on morality. Its essence is though repeated in every book or booklet Nietzsche published. In Human, all too Human (1880-86), we read:

Culture and caste.-A higher culture can come into existence only where there are two different castes in society: that of the workers and that of the idle, of those capable of true leisure; or, expressed more vigorously:

The caste compelled to work and the caste that works if it wants to. Differences in good fortune and happiness are not the essential element when it comes to the production of a higher culture, in any event, however, the caste of the idle is the more capable of suffering and suffers more, its enjoyment of existence is less, its task heavier. If an exchange between these two castes should take place, moreover, so that more obtuse, less spiritual families and individuals are demoted from the higher to the lower caste and the more liberated in the latter obtain entry into the higher, then a state is attained beyond which there can be seen only the open sea of indeterminate desires. - Thus speaks to us the fading voice of ages past, but where are there still ears to hear it? (Nietzsche, 1996: p. 161)

This theory is completely unacceptable for post-modernists, as they would call for a de-construction of the central terms: "noble" values and "aristocracy"-the rule of aristos $=$ the best:Qui bono?

\section{Implications of Aristocratic Values}

We will spell out what is entailed in an "aristocratic society" by looking at the subsequent values that Nietzsche propagates throughout his scholarship.

\section{a) Rejection of compassion}

Globalisation fosters awareness of compassion. With many million poor and handicapped, compassion appears completely legitimate. There is a global conscience about the terrible fate of the new persons in slavery, the trafficking of children and the premature death from starvation of the children in Muslim countries. This ideal of compassion is to be found in the theory of liberal egalitarianism (Hirose, 2014), which is represented by several moral philosophers today: Rawls (1971), Dworkin (2000), Barry (1995) and Sen (2009), or Adam Smith long ago-sympathy (Smith, 2010):

1) Compassion for individual choice, endorsing the liberty of the person;

2) Compassion for impartiality between individuals whatever group they belong to. 
E.g. Nietzsche endorsed the Indian caste system, now forbidden in the modern constitution of the county. Untouchables have been recruited for highest offices. The caste valuations may still plague India informally, but compassion has considerably reduced its relevance and acceptability. Yet, Nietzsche did not hesitate to write in the booklet The Twilight of Idols (1888):

Let us take the other case of so-called morality, the breeding of a particular race or type. The most magnificent example can be found in Indian morality, where it is given religious sanction as the "law of Manu". This law sets the task of breeding no fewer than four races at once: a priestly race, a warrior race, a merchant and agricultural race, and finally a servant race, the Sudras. Clearly, we are not talking about taming animals any more: even to conceive of a breeding scheme like this presupposes a type of person who is a hundred times gentler and more reasonable. You breathe freely again when you leave the Christian atmosphere of disease and dungeon and enter this healthier, higher, more expansive world. What a miserable book the New Testament is in comparison with Manu, how bad it smells! (Nietzsche, 2005: p. 184)

Here, we encounter the so-called "Arian myth", which evidently Nietzsche believed in, although now discarded entirely; and he brings out his theory of Judaism and Christianity as the moral revolt against the strong and noble, i.e. no compassion with the "chandalas" and their suffering due to the customs or institutions of Manu:

“...These decrees are instructive enough: they present us with Aryan humanity for once, in its pure and primordial form, - we learn that the concept of pure blood is anything but harmless. On the other hand, it is clear which people represent the eternal hatred, the Chandala-hatred of this 'humanity', where this hatred has become a religion, where it has become genius"... (Nietzsche, 2005: p. 185)

\section{b) Rebuttal of Socialism and Liberalism}

Nietzsche deals with compassion when discussing socialism as well as liberalism and their moral foundations in Human, all too Human (1880-86)-one of his biggest books, examining lots of aspects of morality. I will make one quotation:

Genius incompatible with the ideal state. - The Socialists desire to create a comfortable life for as many as possible. If the enduring homeland of this comfortable life, the perfect state, were really to be attained, then this comfortable life would destroy the soil out of which great intellect and the powerful individual in general grows: by which I mean great energy. If this state is achieved mankind would have become too feeble still to be able to produce the genius. Ought one therefore not to desire that life should retain its violent character and savage forces and energies continue to be called up again and again? (Nietzsche, 1996: p. 112)

Nietzsche succeeds in this passage to reject both classical liberalism (Bentham's formula "Greatest happiness principle") and socialism that focuses upon the state. Both these ideologies are self-destructive. It is difficult to agree with 
this separation between intelligence and a warm heart. For Nietzsche, the state has other objectives than the overall welfare of its citizens. Perhaps "the greatest intellect" needs democratic control of the by the poor intellects!

Interestingly, Nietzsche rejects all forms of state dominance in society, which would include not only Communism but also National Socialism:

"Socialism can serve to teach, in a truly brutal and impressive fashion, what danger there lies in all accumulations of state power, and to that extent to implant mistrust of the state itself. When its harsh voice takes up the watchword'as much state as possible it thereby at first sounds noisier than ever: but soon the opposite cry comes through with all the greater force: 'as little state as possible." (Nietzsche, 1996: p. 174)

Modern social structure has broken down each and every caste society, completely delegitimized by modernisation as well as post-modernisation. Democracy calls all to the election boxes, and the market economy rewards who ever display the necessary skills, at least in general. However, also the unfortunate have rights, i.e. can legitimately claim support, assistance and sympathy.

\section{c) Adoration of great men}

The key words with Nietzsche are emancipation, self-realization and expressiveness. Nietzsche's originality is no doubt his subjectivism in a period when the dominant philosophy was positivistic, underlining objectivity; this makes him a major forerunner to the post-modernist revolution after the Second World War as well as with Dane Kierkegaard a source of inspiration for existentialism. But he failed miserably with regard to the concept of equality and its increasing value for humanity.

One of his favourites was the Roman dictator G.J. Caesar:

"The means by which Julius Caesar defended himself against sickliness and headaches. tremendous marches, the most frugal way of life, uninterrupted sojourn in the open air, continuous exertion-these are, in general, the universal rules of preservation and protection against the extreme vulnerability of that subtle machine, working under the highest pressure, which we call genius." (Nietzsche, 2005: p. 207)

And Nietzsche's ideal society with a proper social stratification was the Roman Republic and its Empire:

What stood as aere perennius, the imperium Romanum, the most magnificent form of organization ever to be achieved under difficult conditions, compared to which everything before or after has just been patched together, botched and dilettantish, those holy anarchists made a "piety" out of destroying "the world", which is to say the imperium Romanum, until every stone was overturned,-until even the Germans and other thugs could rule over it... The Christian and the anarchist. both are decadents, neither one can do anything except dissolve, poison, lay waste, bleed dry, both have instincts of mortal hatred against everything that stands, that stands tall, that has endurance, that promises life a future...

This organization was stable enough to hold up under bad emperors: the ac- 
cident of personalities cannot make any difference with things like this,-first principle of all great architecture (Nietzsche, 2006: pp. 60-62).

Nietzsche's endorsement of the Roman civilization as one of the truly great ones stems from his admiration of Roman society and its social stratification, based upon the instruments of force and power such as: the legions, its law and institutions, grand scale infrastructure and architecture, massive slavery, domination of other peoples and the relentless employment of physical violence.

During the Republic, government was highly institutionalized, whereas the Empire was characterized by increasing arbitrariness, ending in oriental despotism like government. The use and abuse of power occurred frequently the Republic, while it became daily concern under the Empire. During the Republic, the neighbouring peoples were subjugated or enslaved in a long series of war, besides the occurrence of civil wars within Rome. The Empire brought about huge extension of empire territory, opening it up for constant incursions of so-called barbarians. Sometimes the Empire was governed by insane emperors, resulting in turmoil and civil war.

The larger the territory of Rome, the more violent conflicts became. Defensive war or offensive ones were conducive to making Rome a garrison state. The army became the first priority of the state: how to feed it, how to control it, and how to pay the soldiers during and after combat? Mutiny was frequent, as the army always wanted extra money. It sometimes appointed the Emperor. As the wars become more frequent, getting more soldiers was so urgent that also barbarians could be enrolled. Enormous undertakings to construct fortresses to shield off the borders from outsiders were done at high costs but will no permanent positive results. In sum, Rome was a martial republic or empire with a dire social stratification, over 40 per cent of its population being slaves (Southern, 2016; Joshel, 2010; Erdkamp, 2013).

Rome was also Colosseum and its enormous undertakings in various gaming. Where ever the Romans settle down, they established the business of gladiators and beats killing humans. It was an enterprise of gigantic scale, especially when Christians were persecuted. "Panem et circences" constituted the chief concerns of Romans, who did not participate in the war machine. Bread and circus, said Roman satirist Juvenal (1998), were the gifts to the weaker or poorer strata. Lots of animals were imported monthly from Africa (Wallis, 2016; Auguet, 2012; Dowling, 2000).

Nietzsche's hero, the "noble" Caesar represented this civilization to 100 per cent. His war against Gaul brought him numerous slaves from each tribe to sell to Rome, providing him with a huge fortune to use for bribery and his army. Gaul suffered a heavy decline in population as a result of Caesar's conquest. But the Roman Republic could not be saved from Caesar's march to Rome and he contributed to the creation of the Roman Imperator during the principate.

d) Contradictio in adiecto: amor fati, eternal recurrence and will to power

Based upon his theory of social stratification, Nietzsche taught that human 
beings have to put up with their position in society, be it high or low. He actually adhered to determinism, rejecting the notion of free will. Employing the strange Indian notion of eternal recurrence, the lower strata could only hope for an improvement in the next life, enduring their hardships magnanimously-amor fati. However, this social determinism cannot be congruent with his doctrine of the will to power as the fundamental drive of human beings. It presupposes choice and mistake, as voluntarism entails free will. Men and women can alter social structure by policy-making, enhancing social justice, e.g. in accordance with liberal egalitarianism.

Why would the lower strata accept or even endorse Nietzschean social stratification with all its negative features? He replies: a) amor fat; b) the Eternal recurrence, because Nietzsche has no concept of free will. Both a) and b) are merely Indian philosophical nonsense.

\section{Kierkegaard against Nietzsche}

Much has been written about Nietzsche's hypothesis about human motivation, namely the will to power. It is one-sided for sure, but hardly very sensational. On the one hand, one encounters this motivation with several political philosophers. On the other hand, it seems relevant for understanding the life of many politicians or statesmen. What is highly debatable is the Nietzsche rejection of the idea of free will. How to square this renunciation with the motivation: a will to power?

For any motivation assumption, be it money, power, sex prestige, would hold the mean-end generalisation of Max Weber (1949: p. 52):

"Every thoughtful reflection on the ultimate elements of meaningful human action is bound primarily to the categories of 'means' and 'ends" (trans. Shils and Finch, Methodology).

People maximizing power would at every moment face choices about how to do that, meaning choices as well as freedom to choose. Bu Nietzsche has no place for the idea of free will in his philosophy. Let us make a few telling quotations:

Freedom of will and isolation of facts. - Our usual imprecise mode of observation takes a group of phenomena as one and calls it a fact: between this fact and another fact it imagines in addition an empty space, it isolates every fact. In reality, however, all our doing and knowing is not a succession of facts and empty spaces but a continuous flux. Now, belief in freedom of will is incompatible precisely with the idea of a continuous, homogeneous, undivided, indivisible flowing: it presupposes that every individual action is isolate and indivisible; it is an atomism in the domain of willing and knowing. (Nietzsche, 1996: p. 306)

Nietzsche adduces his herakleitian heritage, referring to life as an endless flux of events- "panta rhei" said the great philosopher from Ephesus. No time for deliberations about ends and means of action, as life is a like a powerful stream of water, carrying everyone along in its determined course. The only comfort is 
the "amor fati" and the eternal recurrence. Is it really "comfort" for lower strata? Well, nothing else exists, as the freedom of will and choices after deliberation are illusions:

But what if the opposite were true: that he is always living in manifold dependence but regards himself as free when, out of long habituation, he no longer perceives the weight of the chains? It is only from new chains that he now suffers:- “freedom of will" really means nothing more than feeling no new chains. (Nietzsche, 1996: p. 306)

Nietzsche even argues that the idea of a free will is an invention of the upper strata to fool the lower strata, hoping in vain for social change.

Here, we must bring forth Kierkegaard. Like Nietzsche, his time of success came after the Second World War. His great achievement is to hand down the first comprehensive analysis of human deliberation and choice, in opposition to German metaphysics, right-wing or left-wing or Schopenhauer's grandiose pessimism.

The understanding of Kierkegaard's philosophy of action has been severely hampered by associating him with a French Marxist like J.P. Sartre as well as the tendency to analyze his life as an entire Freudian neurosis towards one woman (Garff, 1994). This is just not pertinent to the case. His first book-Either/Or (1843) - is one of the absolute masterpieces in Western philosophy, to be followed up with stunning books or booklets on the dimensions of choice: anxiety, remorse, fear, trembling, subjectivity-objectivity, etc. We make a few quotations from Either/Or:

Now in case a man were able to maintain himself upon the pinnacle of the instant of choice, in case he could cease to be a man, in case he were in his inmost nature only an airy thought, in case personality meant nothing more than to be a kobold, which takes part, indeed, in the movements but nevertheless remains unchanged; in case such were the situation, it would be foolish to say that it might ever be too late for a man to choose, for in a deeper sense there could be no question of a choice. The choice itself is decisive for the content of the personality, through the choice the personality immerses itself in the thing chosen, and when it does not choose it withers away in consumption. (Kierkegaard, 1944: p. 138)

Here, Kierkegaard creates a solid foundation for the analysis of human behavior from the micro perspective, anticipating the perspective of $20^{\text {th }}$ century game theory. He had visited Berlin several times, but there he found only macro metaphysics in the lectures of prominent Germans. His originality is high:

You will perceive also in what I have just been saying how essentially my view of choice differs from yours (if you can properly be said to have any view), for yours differs precisely in the fact that it prevents-cogitation involved in weighing the alternatives, not on account of the multiplicity of thoughts which attach themselves to every link in the chain, but rather because there is danger afoot, danger that the next instant it may not be equally in my power to choose, that 
something already hast been lived which must be lived over again. For to think that for an instant one can keep one's personality a blank, or that strictly speaking one can break off and bring to a halt the course of the personal life, is a delusion. The personality is already interested in the choice before one chooses, and when the choice is postponed the personality chooses unconsciously... (Kierkegaard, 1944: p. 138)

The emphasis upon choice has a tremendous theoretical force, with lots of implications that Kierkegaard studied in the next-coming books. In Either/Or, he already anticipates his well-known distinction: between the presence and the future from an action point of view:

As truly as there is a future, just so truly is there an either/or. (Kierkegaard, 1944: p. 146)

With Kierkegaard's choice concept, one may reject Nietzsche's determinism, supported by his irrelevant Indian notions. Social stratification cannot be rationalized by "amorfati" and "eternal recurrence".

\section{Conclusion}

Nietzsche had a well of ideas that he returned to in his books and booklets, not always coherently. His reputation has been much enlarged with post-modernism, as a very early spokesman for subjectivity and human autonomy against prevailing dominant culture. Yet, his theory of social stratification is unacceptable and completely out of tune with both post-modernism and what comes after, namely humanitarianism. With neo-liberalism discarded and socialism in lack of a credible economic system theory, the morality of compassion takes centre stage. The unlucky are so numerous in the globalization era: asylum seekers, refugees, Syria's and Yemen's children, undernourishment in Africa, the Rohingyas, the homeless in the rich world, the eco-refugees, etc. Compassion will not threaten the ruling classes or the capitalist system. We can double UN money for achieving compassion for children, starving peasants and handicapped. Compassion implies liberal egalitarianism as social justice, but it also believes in the market economy as the most effective allocation mechanism.

\section{References}

Auguet, R. (2012). Cruelty and Civilization: The Roman Games. London: Routledge.

Barry, B. (1995). Justice as Impartiality. Oxford: OUP.

Davis, K., \& Moore, W. E. (1945). Some Principles of Stratification. American Sociological Review, 10, 242-249. https://doi.org/10.2307/2085643

Dowling, M. B. (2000). Clemency and Cruelty in the Roman World. Ann Arbor: University of Michigan Press.

Dworkin, R. (2000). Sovereign Justice. Cambridge: Harvard U.P.

Erdkamp, P. (2013). The Cambridge Companion to Ancient Rome. Cambridge: Cambridge U.P.

Garff, J. (1994). Soren Kierkegaard. A Biography. Princeton: Princeton U.P.

Hirose, I. (2014). Egalitarianism. London: Routledge. 
Joshel, S. R. (2010). Slavery in the Roman World. Cambridge: Cambridge U.P.

Juvenal, (1998). The Sixteen Satires. London: Penguin.

Kierkegaard, S. (1944). Either/Or. Princeton: Princeon U.P.

https://ia601907.us.archive.org/13/items/in.ernet.dli.2015.188763/2015.188763.EitherOr-Vol-Ii_text.pdf

Lanier Anderson, R. (2017). Friedrich Nietzsche. The Stanford Encyclopaedia of Philosophy (Summer Edition).

https://plato.stanford.edu/archives/sum2017/entries/nietzsche/

Magnus, B., \& Higgins, K. (1996). The Cambridge Companion to Nietsche. Cambridge: Cambridge U.P. https://doi.org/10.1017/CCOL0521365864

Nietzsche, F. (1996). Human, All Too Human. Cambridge: Cambridge U.P.

Nietzsche, F. (1997a). Daybreak. Cambridge: Cambridge U.P.

Nietzsche, F. (1997b). Untimely Meditations. Cambridge: Cambridge U.P. https://doi.org/10.1017/CBO9780511812101

Nietzsche, F. (1999). The Birth of Tragedy. Cambridge: Cambridge U.P.

Nietzsche, F. (2000). Beyond Good and Evil. Cambridge: Cambridge U.P.

Nietzsche, F. (2001). The Gay Science. Cambridge: Cambridge U.P. https://doi.org/10.1017/CBO9780511812088.005

Nietzsche, F. (2005). The Anti-Christ, Ecce Homo, Twilight of the Idols. Cambridge: Cambridge U.P.

Nietzsche, F. (2006). On the Genealogy of Morals. Cambridge: Cambridge U.P.

Rawls, J. (1971). A Theory of Justice. Cambridge: Harvard U.P

Sen, A. (2009). The Idea of Justice. Cambridge: Harvard U.P.

Smith, A. (2010). The Theory of Moral Sentiments. London: Penguin. https://doi.org/10.1002/9781118011690.ch10

Southern, P. (2016). The Roman Army: A History 753BC-AD476. Location: Amberley Publishing.

Tanner, M. (2011). Nietzsche. Oxford: Oxford U.P.

Wallis, F. H. (2016). Roman Scandal: A Brief History of Murder, Adultery, Rape, Slavery, Animal Cruelty, Torture, Plunder, and Religious Persecution in the Ancient Empire of Rome. Location: CreateSpace Independent Publishing.

Weber, M. (1949). The Methodology of the Social Sciences. New York: Free Press.

Young, J. (2010). Friedrich Nietzsche: A Philosophical Biography. Cambridge: Cambridge U.P. https://doi.org/10.1017/CBO9781139107013 